\title{
Belediye Çalışanlarının Stratejik Planlamaya İlişkin Tutumları: Bursa Yıldırım Belediyesi Örneği (The Attitudes of Municipality Employees Towards Strategic Planning: Bursa Yıldırım Municipality Example)
}

\section{Nilüfer RÜZGAR iD a}

a Bursa Teknik Üniversitesi, İnsan ve Toplum Bilimleri Fakültesi, İşletme Bölümü, Bursa, Türkiye. nilufer.ruzgar@btu.edu.tr

\begin{tabular}{|c|c|}
\hline MAKALE BİLGİSİ & ÖZET \\
\hline $\begin{array}{l}\text { Anahtar Kelimeler: } \\
\text { Stratejik Yönetim } \\
\text { Stratejik Planlama } \\
\text { Belediyeler } \\
\text { Bursa } \\
\text { Yıldırım }\end{array}$ & $\begin{array}{l}\text { Amaç - Stratejik planlama, stratejik yönetim süreci içerisinde yöneticilerin uzun vadeli amaçları } \\
\text { belirlemesini ve örgüt üyelerinin bu amaçları benimseyerek gerçekleştirmelerini sağlayan bir yol } \\
\text { haritasıdır. Bu bağlamda, örgüt üyelerinin bu planlamalara dâhil edilmesi ve planlamalara ilişkin } \\
\text { tutumlarının ölçülmesi önem arz etmektedir. Kamu sektöründe, bilhassa belediyelerde, topluma } \\
\text { hizmetin ön planda olmasından dolayı stratejik planlamanın ve çalışanları sürece dâhil etmenin } \\
\text { önemi daha fazla hissedilmektedir. Bu bağlamda bu çalışmanın amacı, Bursa Yıldırım Belediyesi } \\
\text { çalışanlarının, belediyede uygulanan stratejik planlamaya ilişkin tutumlarını ölçmektir. }\end{array}$ \\
\hline $\begin{array}{l}\text { Gönderilme Tarihi } 28 \text { Haziran } \\
2020 \\
\text { Revizyon Tarihi } 1 \text { Ekim } 2020 \\
\text { Kabul Tarihi } 10 \text { Ekim } 2020\end{array}$ & $\begin{array}{l}\text { Yöntem - Bu kapsamda, Stratejik Planlama Tutum Ölçeği (Baloğlu, Karadağ ve Karaman, 2008) ve } \\
\text { demografik sorulardan oluşan bir anket formu oluşturularak } 546 \text { çalışanı olan Yıldırım Belediyesi'ne } \\
\text { Ekim } 2019 \text { 'da gönderilmiş ve Ocak } 2020^{\prime} \text { de } 300 \text { adet geri dönüş alınmışır. } \\
\text { Bulgular - Elde edilen bulgulara göre belediye çalışanlarının demografik karakteristikleri ile } \\
\text { stratejik planlamaya ilişkin tutumları arasında istatistiksel olarak anlaml bir ilişki } \\
\text { bulunmamaktadır. }\end{array}$ \\
\hline Araştırma Makalesi & $\begin{array}{l}\text { Tartışma - Bu sonucun elde edilmesinin sebebinin, stratejik planlamaya ilişkin tutum ve algının } \\
\text { henüz belediye çalışanlarında tam olarak oturamamış olması olduğu düşünülmektedir. Dolayısıyla, } \\
\text { sosyo-demografik karakteristikler ne olursa olsun, çalışanların tutum ve algısı değişmemektedir } \\
\text { şeklinde yorumlanmıştır. }\end{array}$ \\
\hline
\end{tabular}

\begin{tabular}{|c|c|}
\hline ARTICLE INFO & ABSTRACT \\
\hline $\begin{array}{l}\text { Keywords: } \\
\text { Strategic Management } \\
\text { Strategic Planning } \\
\text { Municipalities } \\
\text { Bursa } \\
\text { Yıldırım }\end{array}$ & $\begin{array}{l}\text { Purpose - Strategic planning, is a roadmap in the strategic management process, that helps } \\
\text { executives define long-term goals and enables members of the organization to adopt these goals and } \\
\text { act accordingly. In this sense, it is important to include the members of the organization in these } \\
\text { plans and to measure their attitudes. In the public sector, especially in the municipalities, the } \\
\text { importance of strategic planning and including the employees into the process is felt even more } \\
\text { because of the importance of community service. The aim of this study is to measure the attitudes } \\
\text { of Bursa Yildirm Municipality employees towards strategic planning implemented in the } \\
\text { municipality. }\end{array}$ \\
\hline $\begin{array}{l}\text { Received } 28 \text { June } 2020 \\
\text { Revised } 1 \text { October } 2020 \\
\text { Accepted } 10 \text { October } 2020\end{array}$ & $\begin{array}{l}\text { Design/methodology/approach - In this context, a questionnaire form that consists Strategic } \\
\text { Planning Attitude Scale (Baloğlu, Karadağ and Karaman, 2008) and demographical questions was } \\
\text { sent to Yıldırım Municipality in October 2019, which has } 546 \text { employees, and } 300 \text { responses were } \\
\text { received in January } 2020 .\end{array}$ \\
\hline Article Classification: & $\begin{array}{l}\text { Findings - According to the findings there is no statistically significant relationship between } \\
\text { municipality employees' demographical characteristics and their attitudes towards strategic } \\
\text { planning. }\end{array}$ \\
\hline Research Article & $\begin{array}{l}\text { Discussion - It is believed that the reason for this result is that the attitude and perception regarding } \\
\text { strategic planning has not yet been fully established in municipal employees. Therefore, it is thought } \\
\text { that regardless of socio-demographic characteristics, employees' attitude and perception cannot be } \\
\text { interpreted as changeable. }\end{array}$ \\
\hline
\end{tabular}




\section{Giriş}

Günümüz dünyası sürekli değişmekte ve gelişmektedir. Bu değişim ve gelişim süreci, özellikle yönetim alanındaki uygulamaları etkilemektedir. Dolayısıyla değişimlere uyum sağlamak ve gelişebilmek adına stratejik yönetim uygulamalarına önem verilmeye başlanmıştır. Stratejik yönetim, belirli bir amaç doğrultusunda belirlenen hedefler bünyesinde uzun süreli ayakta kalmayı amaçlayan bir yönetim türüdür ve planlama, organize etme, yürütme ve kontrol etme aşamalarını barındırmaktadır.

Stratejik yönetim içerisinde ise, stratejik planlama aşaması son derece önemli bir yer tutmaktadır. Stratejik planlama, örgüt amaçlarına yönelik gerekli görülen yol ve araçların belirlenmesi olarak ifade edilebilmektedir. Stratejik planlama, belirli bir süreç içerisinde gerekli görülen düzeni sağlayıcı unsurdur. Bu süreç, bir yol haritası misali yol gösterici olarak değerlendirilebilmektedir. Dolayısıyla stratejik yönetim sürecinin stratejik planlamalar sayesinde başarılı olabileceği rahatlıkla söylenebilmektedir.

Stratejik planlamaların en çok uygulandığı alanlardan biri de kamu kurum ve kuruluşlarıdır. Bunun başlıca sebebi ise, stratejik yönetim uygulamalarının uzun dönemi kapsayan bir süreç olmasıdır. Bu bağlamda da, kamu kurum ve kuruluşları uzun vadeli planlamalar yapmaya ihtiyaç duydukları ve bu planlamalar vasıtasıyla yine uzun vadeli amaçlarına ulaşmayı hedefledikleri için, stratejik planlamalara büyük önem vermektedirler.

Kamu kurum ve kuruluşlarının arasında bulunan belediyeler ise, stratejik yönetim uygulamalarını benimseyen ve uygulayan kilit kurumlar arasındadır. Bunun en önemli sebebi, belediyelerin halka hizmet amacı taşıması ve yaptıkları stratejik planlamaların halkı memnun etme amacını taşıyor olmasıdır. Gerek büyükşehir gerekse il ve ilçe belediyeleri, stratejik yönetim ve stratejik planlamalara, yukarıda da değinildiği üzere, uzun vadeli hedeflere etkili ve verimli bir şekilde ulaşabilmek için ve daha da önemlisi çalışanlarını da bu sürece dâhil ederek aynı hedefler doğrultusunda ilerlemelerini sağlamak için, ihtiyaç duymaktadırlar. Dolayısıyla, belediyelerin uyguladıkları stratejik planlamaların çalışanlar üzerinde etkili olduğu gerçeği göz önünde bulundurulduğunda çalışanların stratejik planlamaları nasıl algıladıkları, büyük önem arz etmektedir. Bu bağlamda bu çalışmanın amacı, Bursa Yıldırım Belediyesinde uygulanan stratejik planlamamalara ilişkin belediye çalışanlarının tutumunu ölçmektir. Bu çerçevede demografik sorulardan ve Baloğlu, Karadağ ve Karaman (2008) tarafından geliştirilen Stratejik Planlama Tutum Ölçeğinden oluşan bir anket formu kullanılmıştır. Anket formları 546 çalışanı olan Yıldırım Belediyesi'ne e-posta yoluyla gönderilmiş olup 300 adet geri dönüş sağlanmıştır. Elde edilen veriler, SPSS 22.0 paket programı kullanılarak analiz edilmiştir.

\section{Stratejik Yönetim}

Strateji kavramı yüzyıllar boyunca askeri bir kavram olarak kullanılmış ve hem savaş sanatı hem de bir savaşta sonuca ulaşabilmek için yapılacak askeri harekâtın planlanması ve uygulanması olarak literatürde yer etmiştir. Stratejik yönetim ise, 20. yüzyılın ortalarında ortaya çıkmış bir kavram olup örgütlerin uzun dönemde yaşamını devam ettirebilmek ve sürdürülebilir rekabet üstünlügü ve dolayısıyla ortalama kar üzerinde getiri sağlayabilmek amacıyla eldeki üretim kaynaklarının (doğa, insan, sermaye, alt yapı, hammadde) etkili ve verimli olarak kullanılmasıdır (Ülgen ve Mirze, 2010: 30). Stratejik yönetimin esas görevi, bir işin misyonunu başından sonuna detaylıca düşünüp planlamaktır. Ayrıca, "bizim işimiz nedir, ne olmalıdır?" gibi sorular da sorarak belirli hedefler doğrultusunda belirlenen düşüncelerle gelecekte elde edilmesi istenen sonuçları, yani vizyonu da belirlemektir (Drucker, 1999: 53).

Stratejik yönetim iktisadi, idari ve sosyal şartlara bağlı olarak zaman içerisinde değişiklik göstermiştir (Akgemci, 2013:16). Tarihsel döngü içerisinde stratejik yönetim çeşitli alt başlıklar altında da değerlendirilmiş ancak; gelişen toplum yapısıyla bu alt başlıklar da değişiklik göstermiştir. Strategic Management Society (Stratejik Yönetim Topluluğu), stratejik yönetimi 12 temel başlık altında değerlendirilmektedir. Bunlar; Davranışsal Strateji, Rekabet Stratejisi, İş birliği Stratejisi, Kurumsal Strateji, Girişimcilik ve Strateji, Küresel Strateji, Bilgi ve İnovasyon, Paydaş Stratejisi, Stratejik İnsan Kaynağı, Stratejik Liderlik ve Yönetişim, Strateji Pratiği, Strateji Süreci'dir (Durgun, 2017).

Öte yandan, yanlış anlamaların ve yanlış uygulamaların önüne geçebilmek adına stratejik yönetimin ne olmadığına da değinmek önem arz etmektedir. Stratejik yönetim, bir örgütün hiçbir risk almadan yönetim faaliyetlerini gerçekleştirmesi değildir. Kısacası, sakin sularda seyahat etmek gibi algılanmamalıdır. Stratejik 
yönetim, yukarıda da değinildiği üzere, belirlenen hedeflere ulaşmak için bu hedefler doğrultusunda planlı ve sistematik bir biçimde hareket etmektir (Ünaldı, 2002: 1).

Anlaşılabileceği üzere stratejik yönetim, bir örgütün geleceğe yönelik hedeflerini ve bu hedeflere ulaşmayı sağlayacak yolları kapsayan bir karar verme sürecidir (Barry, 1986: 10).

Stratejik yönetim, karar verme süreçlerinde çeşitli araçlardan yararlanmaktadır. Bu araçlar; SWOT Analizi, Portföy Analizleri, Q-Sort Analizi, Senaryo Analizi, Arama Konferansı, Delphi Tekniği, Nominal Grup, Multivoting, Açık Grup, Kalite Çemberleri, Fayda-Maliyet Analizi ve Risk Analizi olarak sıralanabilmektedir. Bu yönetim teknikleri karar verme süreçlerini kolaylaştırmaktadır (Aktan, 2008: 4).

Stratejik yönetim süreci, stratejik bilinçe sahip olmayla başlamaktadır. Stratejik bilince sahip örgütlerin yöneticileri (Thompson, 2001: 303);

- Rakiplerinin sürekli farklı strateji uygulamadıklarının farkında olmakta

- Stratejilerin etkinliğini sağlamak ve nasıl daha etkili olup geliştirilebileceği üzerine düşünmekte

- Değişiklik için çevresel durumlardan nasıl yararlanabileceğini anlayıp bu doğrultuda hareket etmektedir

Stratejik yönetim sürecinin aşamaları ise, 3 basamaktan oluşmaktadır (Aktan, 2008: 4):

- Stratejik Planlama ve Stratejilerin Geliştirilme Aşaması: Bu aşama üst yöneticiler tarafından SWOT analizi yapılan süreci kapsamaktadır. Buradaki asıl amaç, örgütün iç ve dış çevresinin değerlendirilmesidir. Stratejik kararların alınması ve stratejik seçimlerin sağlanması bu aşamada gerçekleşmektedir

- Stratejilerin Uygulanabilirliği: Üst yönetim sorumluluğu altında ve orta kademe yöneticilerle iş birliği yaparak stratejilerin uygulanma aşamasıdır

- Uygulanan Stratejilerin Denetimi ve Gözden Geçirilmesi: Bu süreçte ise, yapılan uygulamaların sonuçları değerlendirilmekte ve gerek duyulursa değişiklikler yapılmaktadır

Örgütlerin stratejik durumunu belirlemek ve planlamaları yapmak, üst yönetimin sorumluluğundadır; ancak örgüt iç ve dış çevresi hakkındaki veriler, birim yöneticilerinden elde edilmektedir (Dinçer, 1998: 18).

\section{Stratejik Planlama}

Stratejik planlama, sonuç almaya yönelik çabaların tamamını içeren bir süreçtir. Bu süreç, örgütün her kademesinde görev alan çalışanların katılımından ve örgüt yöneticilerinin tam desteğini barındıran sonuç odaklı çabalardan meydana gelmektedir (Küçüksüleymanoğlu, 2008: 404).

Stratejik planlama, yukarıda da değinildiği üzere, bir örgütün belirli amaç ve hedefleri doğrultusunda tanımlanan ve güncel kararlar alabilmek amaçlı geliştirilen sistematik bir süreçtir ve geri bildirim yolu ile beklenilen ve gerçekleşen durumlar bağlamında alınan karar ve sonuçların değerlendirilerek gerekli görüldüğünde revize edilmesidir (Johnson, 1994: 8).

Stratejik planlama, örgütün yönünü belirlemektedir. Örgütün nerede olduğunu ve nereye gitmek istediğini şekillendirmekte, gitmek istediği yere nasıl ulaşacağını belirlemektedir (Arabacı, 2007: 89).

Stratejik planlama süreci 5 aşamadan oluşmaktadır (Tapinos vd, 2005: 371):

- Hedef ve amaçların belirlenmesi

- Durum analizinin yapilması

- Alternatif düşünceler oluşturulması

- Uygulama

- Değerlendirme

Stratejik planlama süreci için yapılan hazırlık çalışmaları ise, bu sürece temel oluşturduğu için daha da büyük önem arz etmekte ve üç temel aşamadan meydana gelmektedir (Türkiye Cumhuriyeti Kalkınma Bakanlığı, 2018: 8): 
- Planların sahiplenilmesi

- Planlama sürecinin organizasyonu

- Hazırlık programlarının oluşturulması

Stratejik planlamaların önem teşkil etmesinin temel nedenlerine bakılacak olduğunda değişimin evrensel bir boyutta önem kazanması, teknolojik alanda meydana gelen hızlı değişim, rekabetin her geçen gün artması ve demokratikleşme gibi faktörler başlıca nedenler arasında sayılabilmektedir (Öztop, 2007: 33).

Toparlamak gerekirse stratejik planlama, tüm örgütün dâhil edildiği bir süreçtir (Özçam, 2007: 32). Bu bağlamda örgütün ne yaptığını, neden yaptığını, nasıl yaptığını şekillendiren ve yönlendiren bir süreçtir. Kısacası, örgütün bulunduğu konumdan amaçladığı noktaya varmasını kapsayan sürecin tamamını içermektedir (Bayraktar ve Yıldız, 2007: 286). Karar alma ve eylemleri ortaya koymada disiplinli bir durum sergileme olarak da tanımlanabilmektedir (Bryson, 1999:39).

\subsection{Kamu Kurum ve Kuruluşlarında Stratejik Planlama}

Kamu kurum ve kuruluşlarının mevcut kaynakları ve ihtiyaçları değerlendirildiğinde ve asıl amaçlarının halka hizmet olduğu göz önünde bulundurulduğunda, tüm faaliyetlerinin planlı bir şekilde tasarlanarak uygulamaya konmasının ne kadar elzem olduğu anlaşılmaktadır.

Kamu kurumlarının reform hareketlerinin temel noktalarından biri olan, 24/12/2003 tarihli ve 25326 sayılı Resmi Gazete'de yayınlanmış olan 5018 sayılı Kamu Mali Yönetimi ve Kontrol Kanunu çerçevesince, kamu kurum ve kuruluşlarına stratejik planlama yapma yükümlülüğü getirilmiştir (Gürer, 2006: 91). 5018 sayılı kanunda stratejik planlama, "kamu idarelerinin orta ve uzun vadeli amaçlar doğrultusunda, ana ilke ve politikalarla, amaç ve önceliklere dayalı, performans ölçütlerini ve bunlara ulaşmak amaçlı izlenecek yöntemlerle kaynakların dağılımını içeren plan" olarak ifade edilmektedir (Türkiye Cumhuriyeti Kalkınma Bakanlığı, 2018: 8).

Kamu kurum ve kuruluşlarınca stratejik plan hazırlama, uygulama ve değerlendirilmesi aşamalarında önem arz eden faktörler ise, aşağıdaki gibi sıralanmaktadır (Türkiye Cumhuriyeti Kalkınma Bakanlığı, 2018: 8):

- Stratejik yönetimin tüm ana bileşenleri ile daha güçlü bir bağlantı kurulmasını sağlamak

- Kaynakların kullanılmasıyla birlikte hedef ve amaçların gerçekleştirilmesinde etkinliği artırmak

- Performansların değerlendirilmesinin iyi bir şekilde yapılması ve kanıtlara dayalı karar alınmasını sağlanmak

- Kaliteli bir raporlama yapılmasına temel oluşturmak ve şeffaflık sağlayıp hesap verebilir bir anlayışa sahip olmak

Kamu kurum ve kuruluşlarının planlama anlayışı, hem ulusal hem de uluslararası arenada gerçekleşen sosyoekonomik dalgalanmalardan da büyük ölçüde etkilenmektedir. Buna örnek olarak, iki dünya savaşının da ardından Avrupa ülkelerinde sosyal ve ekonomik alanlarda giderek artan ölçüde müdahaleci bir tavrın oluşması verilebilmektedir. Bu bağlamda, müdahaleci tavrın en önemli aracının planlama olduğu söylenebilmektedir (Genç, 2009: 204).

Kamu kurum ve kuruluşlarında stratejik planlama, hedeflenen konuma ulaşmak için gerekli çabaları belirleyip bunları bilinçli uygulamalarla faaliyete geçiren bir süreçtir. Dolayısıyla kamu kurum ve kuruluşlarında görev yapan yöneticiler ve çalışanlar, stratejik planlamaları benimseyip uzun vadeli vizyon oluşturmakta ve kurumun stratejik hedefine doğru ilerlemektedirler (Aydın, 2012: 47).

Toparlamak gerekirse, stratejik planlamada kamu kurum ve kuruluşlarınca esnek ve katılımcı bir yaklaşım benimsendiği söylenebilmektedir. Planlamalar; kurum ve kuruluşların mevcut durumu, misyonu ve ana ilkeleri doğrultusunda vizyon oluşturup bu vizyona uygun amaçlar ve hedefler belirleyerek bunlara ulaşılmasını sağlayan araçlar olarak ele alınmaktadır (Yılmaz, 2003: 82).

\subsection{Belediyelerde Stratejik Planlama}

Bir önceki bölümde değinilen 5018 sayılı Kanuna ek olarak, 5393 sayılı Belediye Kanunu ve 5216 sayılı Büyükşehir Belediyesi Kanunu hükümlerince, nüfusu 50.000 ve üzerindeki tüm belediyelerin stratejik plan hazırlaması zorunlu hale getirilmiştir (Karasu, 2012: 166). Böylece belediyelerde, şehirleri geliştirmek adına 
kullandıkları ulaşım master planları, çevre düzeni planı gibi çok sayıda kentsel faaliyet aracı bulunmakla beraber temelde iki araç kullanılmaktadır (Strateji ve Bütçe Başkanlığı, 2019: 1):

- Şehirlerdeki sanayi, konut, yeşil alan, turizm, ulaşım ve dinlence gibi çeşitli işlevlerin mekân üzerinde yerleşimini ve dağılımını sağlayıcı imar planlaması

- Belediye kurumlarının görev, yetki ve sorumlulukları doğrultusunda kaynak kullanım önceliklerini belirleyici stratejik planlama

Belediyeler, toplumsal sorumlulukları yerine getirmesi gereken kamu kurumlarındandır. Dolayısıyla toplumsal dinamizme ayak uydurma, halkın değişen ve gelişen ihtiyaç ve isteklerine cevap verebilmek için sürekli bir değişim ve gelişim içinde olma zorunlulukları bulunmaktadır. Bu bağlamda belediyeler, bir nevi özel sektör mantığıyla hareket etmektedirler de denilebilir. Şöyle ki, toplumun her bireyi belediye için müşteri gibidir ve müşteri odaklı anlayış çerçevesinde belediyelerin, bireylerin ihtiyaç, talep ve beklentilerini karşılama ve herkesi memnun etme gibi elzem sorumlulukları bulunmaktadır. Bu noktada da stratejik planlama ile izlenecek politikaları belirleme, maliyetlendirme, kapasitenin güçlendirilmesini sağlama, hedef ve amaçlar doğrultusunda ilerleyen bir yönetim anlayışı benimseme, bütçelemeyi geliştirme, hesap verme sorumluluğu ve kamu hizmetlerinin arzında yararlanıcı taleplerine duyarlılığın artması gibi amaçlar, belediyeler için öncelikli olmaktadır (Bayraktar ve Yıldız, 2007: 289).

Öte yandan belediyeler, stratejik planlar oluştururken bazı gereklilikleri yerine getirmelidir. Bu gerekliliklere; Kamu Mali Yönetim ve Kontrol Kanunu (KMYKK), Belediye Kanunu, Büyükşehir Belediyesi Kanunu, Devlet Planlama Teşkilatı'nın (DPT) oluşturduğu Stratejik Planlama Kılavuzu ile Kamu İdarelerinde Stratejik Planlamaya İlişkin Usul ve Esaslar Hakkında Yönetmelikte değinilmektedir. Bu bağlamda yasal yükümlülükler ve gereklilikler aşağıdaki gibi sıralanmaktadır (Songür, 2008: 82):

- Belediyelerin stratejik plan hazırlama biçimi, planların oluştuğu zaman ve belediye meclislerinde onaylanma zamanı

- Planların, İçişleri Bakanlığı ve Devlet Planlama Teşkilatı (DPT)’ye iletilme biçimi ve tarihleri

- Stratejik planlarda bulunan unsurlar

- Stratejik planlama örgütünün kurulma biçimi ve örgüt içerisindeki kişi sayısı

- Stratejik planlama uygulamalarının başlatılmasının başkan tarafından iletilme biçimi

- Planların sosyal medyada yayınlanma biçimi

- Stratejik planların bütçeyle ilişkisinin kurulma biçimi ile performans programı ve faaliyet raporunun hazırlanma biçimleri

Belediyelerde stratejik planlama aşamaları ise, aşağıdaki gibi ifade edilmektedir (Strateji ve Bütçe Başkanlığı, 2019: 12):

- Halkın yaşam kalitesini etkileyen ve etkilenmesi olası durumların incelenmesi

- Gelecekte şehrin ulaşmak istediği hedef noktalar doğrultusunda ortak bir anlayış benimsenmesi ve uzlaşma sağlanması

- Belirli hedeflere ulaşmak için belediyelerin kaynaklarını etkin kullanma yollarını belirleyip kurumun nasıl şekillenmesi gerektiğini anlatan sistematik bir süreç oluşturulması

Belediyelerde stratejik plan yapılırken öncelikle tüm birimlerden vizyon ve misyon bildirgeleri ile hedefleri istenir ve bu doğrultuda kurumsal vizyon ve misyon bildirgeleri ile hedefler oluşturulur. Ardından SWOT (Strengths-Güçlü Yönler/ Weaknesses-Zayıf Yönler/ Opportunities-Fırsatlar/ Threats-Tehditler) Analizi yapılarak kurumun güçlü ve zayıf olduğu yönler ile dış çevreden kaynaklanan fırsat ve tehdit unsurları belirlenir. Stratejik plan amaçlara bağlı olarak değerlendirilir ve aksak yönler düzeltilerek uygulamaya devam edilir (Bayraktar ve Yıldız, 2007: 291).

Toparlamak gerekirse belediye stratejik planı, sadece belediye tüzel kişiliği içinde yer alan müdürlük, daire, şube gibi destek ve/veya hizmet birimlerine yön veren bir tür doküman değildir. Belediye stratejik planı aynı zamanda (Strateji ve Bütçe Başkanlığı, 2019:2); 
- Belediyelere bağlı olan, ayrı bütçeli ve kamu tüzel kişiliğine haiz su ve kanalizasyon, ulaştırma ve benzeri hizmetleri sağlayan bağlı idarelere ve

- Belediyelerin doğrudan ya da dolaylı yoldan bağlı oldukları idarelere ve ortak oldukları şirket sermayesinin $\% 50$ 'sinden fazlasına sahip olan belediye şirketlerine stratejik bir çerçeve sağlamaktadır

\subsection{Kamu Kurumu Çalışanlarının Stratejik Planlama Tutumuna İlişkin Yapılan Ulusal Araştırmalar}

Ulusal literatür incelendiğinde, belediye çalışanlarının stratejik planlara ilişkin tutumlarını ölçmeyi amaçlayan çeşitli araştırmalar göze çarpmaktadır. Bu araştırmalardan mevcut çalışmayla en çok ilişkili olduğu düşünülenlere bu bölümde yer verilmeye çalışılmıştır. Uluslararası literatürden çalışmalara yer verilmemesinin sebebi, her ülkenin kamu kurumlarındaki sistemlerin ve uygulamaların farklı oluşudur.

İpekoğlu (2019) tarafından gerçekleştirilen bir araştırmada, Ankara ilinde yer alan ve nüfusu 50.000'in üzerinde olan Büyükşehir, Yenimahalle, Mamak, Çankaya, Keçiören, Altındağ, Polatll, Etimesgut ve Gölbaşı Belediyeleri evren olarak alınmış; örneklem ise bahsi geçen 9 belediyenin farklı birimlerinde görev alan yöneticiler ve belediye çalışanlarından oluşmuştur. "Demografik değişkenlerin (cinsiyet, yaş, eğitim durumu) stratejik planlama bilgi düzeyi üzerinde pozitif yönde etkisi vardır" hipotezi için verilere uygulanan analiz sonuçlarına göre cinsiyet, yaş ve eğitim durumu gibi demografik değişkenlerin diğer boyut ve alt boyutlarda olduğu gibi stratejik planlama bilgisi üzerinde de anlamlı bir etkisinin olmadığ görülmüştür. Bu noktada, mevcut çalışmanın sonuçlarıyla da benzerlik göstermektedir.

Aşgın ve Yaman (2018) tarafından gerçekleştirilen bir araştırmada, 5 Ocak 2015 ve 15 Ocak 2015 tarihleri arasında Kalkınma Bakanlığı tarafından bir AB projesi kapsamında gerçekleştirilen stratejik planlama eğitimine katılan, bakanlıklarda görev yapan 60 uzmana anket uygulanmıştır. Elde edilen bulgulara göre, Türkiye'deki kamu kurum ve kuruluşlarında stratejik planlamanın önemli faydalar sağlayıp sağlamadığ1 hususunda katılımcıların \%61,5'inin stratejik planlamanın kuruma katkısı olan bir süreç olduğu görüşünü benimsedikleri görülmüştür. Mevcut çalışmada da katılımcıların stratejik planlamaya ilişkin olumlu tutum besledikleri sonucu elde edilmesinden dolayı iki çalışmanın benzerlik gösterdiği söylenebilmektedir.

Orhan ve Er (2018) tarafından yürütülen benzer bir araştırmada ise, KOSGEB'de stratejik planlama sürecine ilişkin tutumun değerlendirilmesi amaçlanmıştır. Bulgular, sadece üst yönetim tarafından belirlenen çalışanların planlama sürecine dâhil edilmesi sonucu asıl bilgi sahibi olan saha elemanlarının ve KOSGEB'in asıl hedef kitlesi olan KOBİlerin süreçte yeterince temsil edilmediğini ortaya koymuştur. Deneyimli olan çalışanların stratejik planlama bilgi yeterliliği ve stratejik planlamaya yönelik tutum puanlarının daha yüksek olduğu da bulgular arasındadır.

Gürtunca (2010) tarafından hazırlanan yüksek lisans tezi kapsamında yapılan araştırmada İstanbul, İzmir ve Ankara Büyükşehir Belediyeleri, 2010-2014 Stratejik Planlama Rehberleri temel alınarak incelenmiştir. Bu bağlamda, her üç belediyenin de stratejik hedefler belirledikleri ve bu doğrultuda planlar yaptıkları; ancak planlama mantığını henüz oluşturamadıkları görülmüştür. Bunun temel sebeplerine bakıldığı zaman, her üç belediyenin de sadece yönetim kadrosu tarafından planlamayla ilgili kararların alınıp uygulamaya çalışılması olduğu görülmüştür. Bununla birlikte üç ilin de zayıf yönleri içerisinde personel eğitimleri konusunda yetersiz kalınması bulunmaktadır. Bu da, personelin belli konularda bilinçlenmesinin zaman alacağının göstergesi olarak tespit edilmiştir. Bu noktada, mevcut çalışmada da katılımcıların stratejik planlamalara ilişkin eğitim verilmesini önemsedikleri sonucunun elde edilmesinden dolayı iki çalışma arasında benzerlik olduğu söylenebilmektedir.

\section{Araştırmanın Yöntemi}

Nicel analizler, nesnel ölçümlere ve anket gibi yöntemlerle veri toplayarak yapılan istatistiksel ya da matematiksel analizlere odaklanmaktadırlar. Nicel analizler, rakamsal veri toplayarak bu veriyi kişi gruplarına genellemeye ya da belirli bir fenomeni açıklamaya yoğunlaşmaktadırlar (Babbie, 2010:297).

$\mathrm{Bu}$ araştırmanın ana problemi ve araştırma hipotezi, belediye çalışanlarının demografik karakteristikleri ile stratejik planlamaya ilişkin tutumlarının arasındaki ilişkin "ne" ve "ne ölçüde" olduğuna odaklanmaktadır. 
Buna ek olarak, verilerin belediyedeki tüm çalışanlara genellenmesi planlanmıştır. Bu bağlamda, çalışmanın metodu nicel olarak belirlenmiştir. Veri toplama yöntemi olarak anket formları kullanılmıştır. Hazırlanan anket formları katılımcılara elektronik posta yoluyla iletilmiştir. Bursa şehri, Türkiye'nin 4. büyük şehri olması sebebiyle veri toplama esnasında etkililik sağlamaktadır. Ancak zaman ve maliyet bağlamında tüm belediyelere ulaşmak mümkün olmadığı için araştırma örneklemi Bursa'nın 3 merkez ilçesinden biri olan Yıldırım ilçesi olarak belirlenmiştir. 546 çalışanı olan Yıldırım Belediye'sine anketler ulaştırılmış, her birimden eşit sayıda katılım olmasına dikkat edilmiş ve toplamda 300 katılımcıdan geri dönüş alınmıştır. Elde edilen veriler SPSS 22.0 paket programında analiz edilmiştir. Bulgular, Bursa şehrindeki tüm merkez ilçe belediyelerine (Osmangazi, Nilüfer, Yıldırım) genellenmiştir.

\subsection{Katılımc1 Profili}

Demografik bulgulara göre $155(\% 51,7)$ katılımcı kadın, $145(\% 48,3)$ katılımcı ise erkektir. Yaş dağılımlarına gelindiğinde ise 57 (\%19,0) katılımcının 18-29, 124 (\%41,3) katılımcının 30-39, 93 (\%31,0) katılımcının 40-49, 24 $(\% 8,0)$ katılımcının $50-59$ ve $2(\% 0,7)$ katılımcının 60 ve üstü yaş gruplarında yer aldığı görülmüştür. 206 (\%68,7) katılımcı evli, $94(\% 31,3)$ katılımcı ise bekârdır.

\subsection{Hipotezler}

Ho: Belediye çalışanlarının sosyo-demografik (cinsiyet, yaş, medeni durum, eğitim, gelir) karakteristikleri ile stratejik planlamaya ilişkin tutumları arasında istatistiksel olarak anlamlı bir farklılık bulunmamaktadır.

H1: Belediye çalışanlarının sosyo-demografik (cinsiyet, yaş, medeni durum, eğitim, gelir) karakteristikleri ile stratejik planlamaya ilişkin tutumları arasında istatistiksel olarak anlamlı bir farklılık bulunmaktadır. $\mathrm{h}_{1}: \mu_{1}>$ $\mu 2$

\subsection{Araştırmanın Geçerlilik ve Güvenilirliği (Doğrulama)}

Anket formu iki bölümden oluşmaktadır. İlk bölümde demografik sorular yer almakta, ikinci bölümde Baloğlu, Karadağ ve Karaman (2008) tarafından geliştirilen Stratejik Planlama Tutum Ölçeği yer almaktadır. Okul çalışanlarının stratejik plan tutumlarını ölçme amacıyla geliştirilen orijinal ölçek 35 ifadeden ve 5 boyuttan oluşmaktadır. Ölçekteki ifadelerden 2 tanesi mevcut çalışma için uygun olmamasından dolayı çıarılarak ölçek 33 ifade olarak revize edilerek kullanılmıştır. Orijinal ölçeğin kurumu geliştirme, güvensizlik, etkililik, verimlilik ve direnç olarak adlandırılan 5 boyutu bulunurken mevcut çalışmada ölçek ifadelerinin 2 boyut altında toplandığı görülmüştür. Bu boyutlar etkililik/verimlilik ve kurumu geliştirme olarak adlandırılmıştır. Ölçeğin güvenilirlik analizine göre cronbach's alpha değeri 0,913'tür.

Tablo 1. Ölçeğin Cronbach's Alpha Değeri

\begin{tabular}{llc}
\hline Ölçek & Cronbach's Alpha Değeri & İfade Sayısı \\
\hline Stratejik Planlama Tutum Ölçeği & 913 & 33 \\
\hline
\end{tabular}

\subsection{Araştırmanın Bulguları ve Sonuçları}

\subsubsection{Betimsel İstatistik Sonuçları}

Stratejik Planlama Tutum Ölçeğine ilişkin betimsel istatistik sonuçları, katılımcılara göre en önemli maddenin 3,77 ortalama ile 11. ifade olan "Stratejik plan hazırlamayla ilgili yıl içinde eğitim verilmelidir" düşüncesi olduğunu göstermektedir. Bu noktada, bir önceki bölümde değinilen araştırma örneklerinde de benzer şekilde eğitimin önemsendiği sonuçları da göz önünde bulundurulduğunda, çalışanların bu alanda yetkinliklerini artırmak istedikleri düşünülebilmektedir. İkinci olarak 3,73 ortalama ile 8. ifade olan "Stratejik planlama kurumun başarısını artırır" düşüncesi gelmektedir. Buradan da, belediye çalışanlarının stratejik planlama sürecini ciddiye aldıkları ve bu alanda kendilerini ve dolayısıyla kurumu geliştirmek istedikleri sonucuna varılabilmektedir. Üçüncü sırada ise 3,72 ortalama ile 10. ifade olan "Stratejik planlama bir yönetim planlaması modelidir" düşüncesi yer almaktadır. Bu düşüncenin önemsenmesi de yine çalışanların stratejik planlamaya ilişkin algılarının müspet olduğunu göstermektedir. 
Katılımcıların en az önemli buldukları düşüncenin ise, 2,33 ortalama ile 15. ifade "Stratejik planlama kaynakların boşa harcanmasıdır" düşüncesi olduğu görülmüştür. Bu da benzer şekilde, stratejik planlamanın son derece önemsendiğini ve kuruma katkı yaptığına inanıldığını vurgulama noktasında önem arz etmektedir.

Tablo 2. Betimsel İstatistik Tablosu

\begin{tabular}{|c|c|c|c|c|c|c|c|c|}
\hline İfadeler & & 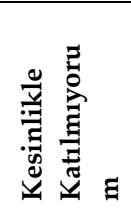 & 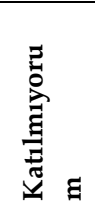 & 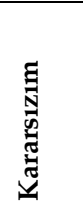 & 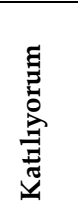 & 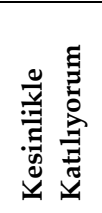 & $x$ & 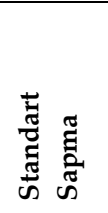 \\
\hline $\begin{array}{lcc}\text { 1- } & \text { Stratejik planlama } & \text { kurumun } \\
\text { denetlenmesini kolaylaştırır } & \\
\end{array}$ & $\begin{array}{l}\text { fi } \\
\text { Y.fi }\end{array}$ & $\begin{array}{l}27 \\
9,0\end{array}$ & $\begin{array}{l}29 \\
9,7\end{array}$ & $\begin{array}{ll}44 \\
14,7\end{array}$ & $\begin{array}{l}119 \\
39,7\end{array}$ & $\begin{array}{l}81 \\
27,0\end{array}$ & 3,66 & 1,22586 \\
\hline $\begin{array}{l}\text { 2- Stratejik planlama kurum çalışanlarının } \\
\text { standardını yükseltir }\end{array}$ & $\begin{array}{l}\text { fi } \\
\text { Y.fi }\end{array}$ & $\begin{array}{l}27 \\
9,0\end{array}$ & $\begin{array}{l}45 \\
15,0 \\
\end{array}$ & $\begin{array}{l}47 \\
15,7 \\
\end{array}$ & $\begin{array}{l}105 \\
35\end{array}$ & $\begin{array}{l}76 \\
25,3 \\
\end{array}$ & 3,52 & 1,26542 \\
\hline $\begin{array}{lcc}\text { 3- } & \text { Stratejik planlama } & \text { yöneticilerin } \\
\text { yeteneklerini ortaya çlkarır } & \\
\end{array}$ & $\begin{array}{l}\text { fi } \\
\text { Y.fi }\end{array}$ & $\begin{array}{l}25 \\
8,3 \\
\end{array}$ & $\begin{array}{l}49 \\
16,3 \\
\end{array}$ & $\begin{array}{l}48 \\
16,0 \\
\end{array}$ & $\begin{array}{l}115 \\
38,3 \\
\end{array}$ & $\begin{array}{ll}63 \\
21,0 \\
\end{array}$ & 3,47 & 1,22514 \\
\hline $\begin{array}{l}\text { 4- Stratejik planlama kurum ihtiyaçlarının } \\
\text { (bina, donanım, personel vb.) gerçekçi bir } \\
\text { şekilde tespit edilmesini sağlar }\end{array}$ & $\begin{array}{l}\text { fi } \\
\text { Y.fi }\end{array}$ & $\begin{array}{l}30 \\
10,00\end{array}$ & $\begin{array}{l}31 \\
10,3\end{array}$ & $\begin{array}{l}39 \\
13,01\end{array}$ & $\begin{array}{l}121 \\
40,3\end{array}$ & $\begin{array}{l}79 \\
26,3\end{array}$ & 3,62 & 1,25401 \\
\hline $\begin{array}{l}\text { 5- Stratejik planlama kurumdaki etkili } \\
\text { iletişim düzeyini artırır }\end{array}$ & $\begin{array}{l}\text { fi } \\
\text { Y.fi }\end{array}$ & $\begin{array}{ll}35 \\
11,7 \\
\end{array}$ & $\begin{array}{l}42 \\
14,0 \\
\end{array}$ & $\begin{array}{l}53 \\
17,7 \\
\end{array}$ & $\begin{array}{l}105 \\
35,7\end{array}$ & $\begin{array}{ll}63 \\
21,0 \\
\end{array}$ & 3,40 & 1,28302 \\
\hline $\begin{array}{l}\text { 6- Stratejik planlama yöneticilerin } \\
\text { sorumluluk duygusunu geliştirir }\end{array}$ & $\begin{array}{l}\text { fi } \\
\text { Y.fi }\end{array}$ & $\begin{array}{l}25 \\
8,3 \\
\end{array}$ & $\begin{array}{l}39 \\
13,0\end{array}$ & $\begin{array}{l}51 \\
17,0 \\
\end{array}$ & $\begin{array}{l}121 \\
40,3 \\
\end{array}$ & $\begin{array}{l}64 \\
21,3 \\
\end{array}$ & 3,53 & 1,20015 \\
\hline $\begin{array}{l}\text { 7- Stratejik planlama grup çalışmalarını } \\
\text { etkin kılar }\end{array}$ & $\begin{array}{l}\text { fi } \\
\text { Y.fi }\end{array}$ & $\begin{array}{l}23 \\
7,7\end{array}$ & $\begin{array}{l}39 \\
13,0\end{array}$ & $\begin{array}{l}38 \\
12,7 \\
\end{array}$ & $\begin{array}{l}128 \\
42,7\end{array}$ & $\begin{array}{l}72 \\
24,0 \\
\end{array}$ & 3,62 & 1,19983 \\
\hline $\begin{array}{l}\text { 8- Stratejik planlama kurumun başarısını } \\
\text { artııır }\end{array}$ & $\begin{array}{l}\text { fi } \\
\text { Y.fi }\end{array}$ & $\begin{array}{l}20 \\
6,73 \\
\end{array}$ & $\begin{array}{l}31 \\
13,0 \\
\end{array}$ & $\begin{array}{ll}41 \\
13,71\end{array}$ & $\begin{array}{l}124 \\
41,3 \\
\end{array}$ & $\begin{array}{l}84 \\
28,0 \\
\end{array}$ & 3,73 & 1,16842 \\
\hline $\begin{array}{l}\text { 9- Stratejik planlama geleceğe ilişkin } \\
\text { alternatif politikalar üretir }\end{array}$ & $\begin{array}{l}\text { fi } \\
\text { Y.fi }\end{array}$ & $\begin{array}{l}25 \\
8,3 \\
\end{array}$ & $\begin{array}{l}27 \\
9,0 \\
\end{array}$ & $\begin{array}{ll}56 \\
18,71 \\
\end{array}$ & $\begin{array}{l}139 \\
46,3 \\
\end{array}$ & $\begin{array}{ll}53 \\
17,7 \\
\end{array}$ & 3,56 & 1,13314 \\
\hline $\begin{array}{l}\text { 10- Stratejik planlama bir yönetim } \\
\text { planlaması modelidir }\end{array}$ & $\begin{array}{l}\text { fi } \\
\text { Y.fi }\end{array}$ & $\begin{array}{l}19 \\
6,3\end{array}$ & $\begin{array}{l}27 \\
9,0\end{array}$ & $\begin{array}{l}44 \\
14,7\end{array}$ & $\begin{array}{l}139 \\
46,3\end{array}$ & $\begin{array}{l}71 \\
23,7 \\
\end{array}$ & 3,72 & 1,11313 \\
\hline $\begin{array}{l}\text { 11- Stratejik plan hazırlamayla ilgili yıl } \\
\text { içinde eğitim verilmelidir }\end{array}$ & $\begin{array}{l}\text { fi } \\
\text { Y.fi }\end{array}$ & $\begin{array}{l}19 \\
6,3 \\
\end{array}$ & $\begin{array}{l}23 \\
7,7 \\
\end{array}$ & $\begin{array}{l}49 \\
16,3 \\
\end{array}$ & $\begin{array}{l}125 \\
41,7 \\
\end{array}$ & $\begin{array}{l}84 \\
28,0 \\
\end{array}$ & 3,77 & 1,12821 \\
\hline 12- Stratejik planlama bir hayal ürünüdür & $\begin{array}{l}\text { fi } \\
\text { Y.fi }\end{array}$ & $\begin{array}{ll}66 \\
22,0 \\
\end{array}$ & $\begin{array}{l}88 \\
29,3 \\
\end{array}$ & $\begin{array}{l}51 \\
17,0 \\
\end{array}$ & $\begin{array}{l}70 \\
23,3 \\
\end{array}$ & $\begin{array}{l}25 \\
8,3 \\
\end{array}$ & 3,66 & 1,27841 \\
\hline $\begin{array}{l}\text { 13- Stratejik planlamada iş planı } \\
\text { hazırlamak daha kolay olur }\end{array}$ & $\begin{array}{l}\text { fi } \\
\text { Y.fi }\end{array}$ & $\begin{array}{l}23 \\
7,7 \\
\end{array}$ & $\begin{array}{l}28 \\
9,3 \\
\end{array}$ & $\begin{array}{l}51 \\
17,0 \\
\end{array}$ & $\begin{array}{l}150 \\
50,0\end{array}$ & $\begin{array}{l}48 \\
16,0 \\
\end{array}$ & 3,57 & 1,10242 \\
\hline 14- Stratejik planlama zaman israfıdır & $\begin{array}{l}\text { fi } \\
\text { Y.fi }\end{array}$ & $\begin{array}{l}94 \\
31,3 \\
\end{array}$ & $\begin{array}{l}89 \\
29,7 \\
\end{array}$ & $\begin{array}{l}46 \\
15,3 \\
\end{array}$ & $\begin{array}{ll}46 \\
15,3 \\
\end{array}$ & $\begin{array}{l}25 \\
8,3 \\
\end{array}$ & 2,39 & 1,29547 \\
\hline $\begin{array}{l}\text { 15- Stratejik planlama kaynakların boşa } \\
\text { harcanmasıdır }\end{array}$ & $\begin{array}{l}\text { fi } \\
\text { Y.fi }\end{array}$ & $\begin{array}{l}93 \\
31,0 \\
\end{array}$ & $\begin{array}{l}102 \\
34,0 \\
\end{array}$ & $\begin{array}{l}40 \\
13,3 \\
\end{array}$ & $\begin{array}{l}41 \\
13,7 \\
\end{array}$ & $\begin{array}{l}24 \\
8,0 \\
\end{array}$ & 2,33 & 1,26570 \\
\hline 16- Stratejik planlama kendini kandırmadır & $\begin{array}{l}\text { fi } \\
\text { Y.fi }\end{array}$ & $\begin{array}{l}97 \\
32,3 \\
\end{array}$ & $\begin{array}{l}96 \\
32,0\end{array}$ & $\begin{array}{l}41 \\
13,7 \\
\end{array}$ & $\begin{array}{l}40 \\
13,3 \\
\end{array}$ & $\begin{array}{l}26 \\
8,7\end{array}$ & 2,34 & 1,28968 \\
\hline $\begin{array}{l}\text { 17- Stratejik planlama, sorumluluğu } \\
\text { başkasının üzerine atmaktır }\end{array}$ & $\begin{array}{l}\text { fi } \\
\text { Y.fi }\end{array}$ & $\begin{array}{l}95 \\
31,7 \\
\end{array}$ & $\begin{array}{l}86 \\
28,7 \\
\end{array}$ & $\begin{array}{l}47 \\
15,7 \\
\end{array}$ & $\begin{array}{l}49 \\
16,3 \\
\end{array}$ & $\begin{array}{l}23 \\
7,7\end{array}$ & 2,39 & 1,29030 \\
\hline $\begin{array}{l}\text { 18- Stratejik planlama bir oyalama } \\
\text { taktiğidir }\end{array}$ & $\begin{array}{l}\text { fi } \\
\text { Y.fi }\end{array}$ & $\begin{array}{ll}92 \\
30,7\end{array}$ & $\begin{array}{ll}88 \\
29,3 \\
\end{array}$ & $\begin{array}{ll}44 \\
14,7 \\
\end{array}$ & $\begin{array}{ll}47 \\
15,7 \\
\end{array}$ & $\begin{array}{l}29 \\
9,7\end{array}$ & 2,44 & 1,32639 \\
\hline $\begin{array}{l}\text { 19- Stratejik planın hazırlanmasına kurum } \\
\text { çalışanları yardımcı olmalıdırlar }\end{array}$ & $\begin{array}{l}\text { fi } \\
\text { Y.fi }\end{array}$ & $\begin{array}{l}20 \\
6,7 \\
\end{array}$ & $\begin{array}{l}30 \\
10,0 \\
\end{array}$ & $\begin{array}{l}45 \\
15,0 \\
\end{array}$ & $\begin{array}{l}140 \\
46,7\end{array}$ & $\begin{array}{l}65 \\
21,7 \\
\end{array}$ & 3,66 & 1,12239 \\
\hline $\begin{array}{l}\text { 20- Stratejik planlama, günü kurtarmaya } \\
\text { yönelik yapılır }\end{array}$ & $\begin{array}{l}\text { fi } \\
\text { Y.fi }\end{array}$ & $\begin{array}{l}68 \\
22,7 \\
\end{array}$ & $\begin{array}{l}98 \\
32,7 \\
\end{array}$ & $\begin{array}{l}54 \\
18,0 \\
\end{array}$ & $\begin{array}{l}54 \\
18,0 \\
\end{array}$ & $\begin{array}{l}26 \\
8,7 \\
\end{array}$ & 2,57 & 1,25827 \\
\hline $\begin{array}{l}\text { 21- Stratejik planlama kaynakların etkin } \\
\text { kullanımını sağlar }\end{array}$ & $\begin{array}{l}\text { fi } \\
\text { Y.fi }\end{array}$ & $\begin{array}{l}17 \\
5,7 \\
\end{array}$ & $\begin{array}{l}36 \\
12,0 \\
\end{array}$ & $\begin{array}{l}52 \\
17,3 \\
\end{array}$ & $\begin{array}{l}140 \\
46,7 \\
\end{array}$ & $\begin{array}{l}55 \\
18,3 \\
\end{array}$ & 3,60 & 1,09116 \\
\hline $\begin{array}{l}\text { 22- Stratejik planlama gerçekçi ve } \\
\text { ulaşllabilir hedeflerle oluşturulur }\end{array}$ & $\begin{array}{l}\text { fi } \\
\text { Y.fi }\end{array}$ & $\begin{array}{l}14 \\
4,7\end{array}$ & $\begin{array}{ll}33 \\
11,0\end{array}$ & $\begin{array}{l}54 \\
18,0 \\
\end{array}$ & $\begin{array}{l}138 \\
46,0\end{array}$ & $\begin{array}{l}61 \\
23,0 \\
\end{array}$ & 3,66 & 1,06479 \\
\hline $\begin{array}{l}\text { 23- Stratejik planlama görev dağılımında } \\
\text { işe uygun personel seçimini sağlar }\end{array}$ & $\begin{array}{l}\text { fi } \\
\text { Y.fi }\end{array}$ & $\begin{array}{l}26 \\
8,7 \\
\end{array}$ & $\begin{array}{l}40 \\
13,3 \\
\end{array}$ & $\begin{array}{l}56 \\
18,7 \\
\end{array}$ & $\begin{array}{l}127 \\
42,3 \\
\end{array}$ & $\begin{array}{l}51 \\
17,0 \\
\end{array}$ & 3,45 & 1,17447 \\
\hline $\begin{array}{l}\text { 24- Stratejik planlama hizmetin kalitesinde } \\
\text { belirgin bir artış sağlar }\end{array}$ & $\begin{array}{l}\text { fi } \\
\text { Y.fi }\end{array}$ & $\begin{array}{l}19 \\
6,3 \\
\end{array}$ & $\begin{array}{ll}30 \\
10,0 \\
\end{array}$ & $\begin{array}{ll}65 \\
21,7 \\
\end{array}$ & $\begin{array}{l}133 \\
44,3 \\
\end{array}$ & $\begin{array}{ll}53 \\
17,7 \\
\end{array}$ & 3,57 & 1,08737 \\
\hline $\begin{array}{l}\text { 25- Stratejik planlama günlük işlerin } \\
\text { kolaylaşmasını sağlar }\end{array}$ & $\begin{array}{l}\text { fi } \\
\text { Y.fi } \\
\end{array}$ & $\begin{array}{l}20 \\
6,7 \\
\end{array}$ & $\begin{array}{l}33 \\
11,0 \\
\end{array}$ & $\begin{array}{ll}60 \\
20,0 \\
\end{array}$ & $\begin{array}{l}141 \\
47,0 \\
\end{array}$ & $\begin{array}{l}46 \\
15,3 \\
\end{array}$ & 3,53 & 1,08604 \\
\hline
\end{tabular}


N. Rüzgar 12/4 (2020) 3702-3713

\begin{tabular}{|c|c|c|c|c|c|c|c|c|}
\hline $\begin{array}{l}\text { 26- Stratejik planlama maddi kaynakların } \\
\text { öncelik sırasına göre kullanılmasında } \\
\text { etkilidir }\end{array}$ & $\begin{array}{l}\text { fi } \\
\text { Y.fi }\end{array}$ & $\begin{array}{l}21 \\
7,0\end{array}$ & $\begin{array}{l}30 \\
10,0\end{array}$ & $\begin{array}{l}66 \\
22,0\end{array}$ & $\begin{array}{l}135 \\
45,0\end{array}$ & $\begin{array}{l}48 \\
16,6\end{array}$ & 3,53 & 1,09228 \\
\hline $\begin{array}{l}\text { 27- Stratejik planlama işlerinde mutlaka } \\
\text { uyum aranmalıdır }\end{array}$ & $\begin{array}{l}\text { fi } \\
\text { Y.fi }\end{array}$ & $\begin{array}{l}19 \\
6,3\end{array}$ & $\begin{array}{l}27 \\
9,0\end{array}$ & $\begin{array}{ll}54 \\
18,0\end{array}$ & $\begin{array}{l}147 \\
42,3\end{array}$ & $\begin{array}{l}58 \\
19,3\end{array}$ & 3,64 & 1,08630 \\
\hline $\begin{array}{l}\text { 28- Stratejik planlama } \\
\text { kullanımını kolaylaştırır }\end{array}$ & $\begin{array}{l}\text { fi } \\
\text { Y.fi }\end{array}$ & $\begin{array}{l}21 \\
7,0\end{array}$ & $\begin{array}{ll}37 \\
12,3 \\
\end{array}$ & $\begin{array}{ll}65 \\
21,7\end{array}$ & $\begin{array}{l}127 \\
42,3\end{array}$ & $\begin{array}{l}50 \\
16,7 \\
\end{array}$ & 3,49 & 1,11988 \\
\hline $\begin{array}{l}\text { 29- Stratejik planlama mali kaynakların } \\
\text { verimliliğini artırır }\end{array}$ & $\begin{array}{l}\text { fi } \\
\text { Y.fi }\end{array}$ & $\begin{array}{l}21 \\
7,0\end{array}$ & $\begin{array}{l}37 \\
12,3\end{array}$ & $\begin{array}{l}58 \\
19,3\end{array}$ & $\begin{array}{l}128 \\
42,7\end{array}$ & $\begin{array}{l}56 \\
18,7\end{array}$ & 3,53 & 1,13709 \\
\hline $\begin{array}{l}\text { 30- Stratejik planlama yeni projeler } \\
\text { üretmeye yardımcı olur }\end{array}$ & $\begin{array}{l}\text { fi } \\
\text { Y.fi }\end{array}$ & $\begin{array}{l}22 \\
7,3\end{array}$ & $\begin{array}{l}27 \\
9,0\end{array}$ & $\begin{array}{l}39 \\
13,0\end{array}$ & $\begin{array}{l}147 \\
49\end{array}$ & $\begin{array}{l}65 \\
21,7 \\
\end{array}$ & 3,68 & 1,12815 \\
\hline 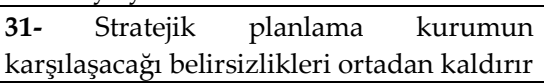 & $\begin{array}{l}\text { fi } \\
\text { Y.fi }\end{array}$ & $\begin{array}{l}20 \\
6,7\end{array}$ & $\begin{array}{l}33 \\
11,0\end{array}$ & $\begin{array}{l}67 \\
22,3\end{array}$ & $\begin{array}{l}138 \\
46,0\end{array}$ & $\begin{array}{l}41 \\
14,0\end{array}$ & 3,49 & 1,07417 \\
\hline $\begin{array}{l}\text { 32- Stratejik planlama yapanlar, bu planlar } \\
\text { yoluyla kendi } \quad \text { düşüncelerini } \\
\text { gerçekleştirmek isterler }\end{array}$ & $\begin{array}{l}\text { fi } \\
\text { Y.fi }\end{array}$ & $\begin{array}{l}39 \\
13,0\end{array}$ & $\begin{array}{l}76 \\
25,3\end{array}$ & $\begin{array}{l}80 \\
26,7\end{array}$ & $\begin{array}{l}72 \\
24,0\end{array}$ & $\begin{array}{l}33 \\
11,0\end{array}$ & 2,94 & 1,20637 \\
\hline $\begin{array}{l}\text { 33- Stratejik planlama çalışanlar arasında } \\
\text { gruplaşmalara neden olur }\end{array}$ & $\begin{array}{l}\text { fi } \\
\text { Y.fi }\end{array}$ & $\begin{array}{ll}52 \\
17,3 \\
\end{array}$ & $\begin{array}{l}88 \\
29,3 \\
\end{array}$ & $\begin{array}{l}83 \\
27,7 \\
\end{array}$ & $\begin{array}{ll}51 \\
17,0\end{array}$ & $\begin{array}{l}26 \\
8,7\end{array}$ & 2,70 & 1,19166 \\
\hline
\end{tabular}

\subsubsection{Faktör Analizi Sonuçları}

Yapılan faktör analizine göre (Tablo 3), Stratejik Planlama Tutum Ölçeğinin orijinal ölçekten farklı olarak iki boyut altında toplandığı görülmüştür. Bu boyutlar, orijinal ölçeğe de bağlı kalmak suretiyle, Etkililik/Verimlilik ve Kurumu Geliştirme olarak adlandırılmıştır. Etkililik/Verimlilik boyutu Stratejik Planlama Tutum Ölçeğini 38,527'lik bir yüzdeyle açıklarken Kurumu Geliştirme boyutu 32,819'luk bir yüzdeyle açıklamaktadır. Her iki boyutun kümülatif yüzdesi ise, 71,346 olarak bulunmuştur.

Tablo 3. Açıklanan Toplam Varyans

\begin{tabular}{lllllll}
\hline & \multicolumn{2}{c}{ Hesaplanmiş Kareler Toplamı } & & \multicolumn{2}{c}{ Döndürülmüş Kareler Toplamı } \\
\cline { 2 - 6 } & \multicolumn{3}{c}{ \% } & & & \\
Bileşen & Total & Varyans & Kümülatif\% & Total & \%Varyans & Kümülatif\% \\
\hline 1 & 15,024 & 65,321 & 65,321 & 8,861 & 38,527 & 38,527 \\
2 & 1,386 & 6,026 & 71,346 & 7,548 & 33,819 & 71,346
\end{tabular}

\subsubsection{Karşılaştırmalı İstatistik Sonuçları}

Faktör analizi sonucunda elde edilen boyutlara ilişkin, katılımcıların sosyo-demografik bulgularına göre verdikleri yanıtlarında istatistiksel olarak farklılık olup olmadığı, Mann-Whitney U ve Kruskal-Wallis testleri ile analiz edilmiştir (Tablo 4). Elde edilen boyutların katılımcıların sosyo-demografik yapılarından cinsiyet, medeni durum, yaş ve gelir karakteristiklerinde istatistiksel olarak anlamlı bir farklılık göstermediği $(p>0,05)$ sonucuna varılmıştır. Dolayısıyla $\mathrm{H}_{0}$ hipotezi kabul edilmiştir. Öte yandan, eğitim karakteristiklerinde örgüt geliştirme boyutu kapsamında istatistiksel olarak anlamlı bir farklılık olduğu görülmüştür $(p<0,05)$. Bundan dolayı da $\mathrm{H}_{1}$ hipotezi kısmen kabul edilmiştir; ancak diğer demografik karakteristiklerde istatistiksel olarak anlamlı bir farklılık bulunmamasından dolayı, büyük ölçüde reddedilmiştir. Bunun sebebinin ise, stratejik planlamaya ilişkin tutum ve algının, her ne kadar betimsel istatistik sonuçlarına göre olumlu bir tablo çizilse de, henüz kamu kurumu çalışanlarında tam olarak oturamamış olması olduğu düşünülmektedir. Bunun sebebi ise, yukarıda da değinildiği üzere bu alanda verilen eğitimin yeterli olmayışı durumu olarak düşünülebilmektedir. Böylece, sosyo-demografik karakteristikler ne olursa olsun stratejik planlamaya ilişkin tutum ve algı değişmemektedir şeklinde yorumlanabileceği düşünülmektedir. 
N. Rüzgar 12/4 (2020) 3702-3713

Tablo 4. Karşılaştırmalı İstatistik Sonuçları

\begin{tabular}{|c|c|c|c|c|}
\hline Değişken & Boyut & Test & İstatistikler & $\mathbf{P}$ \\
\hline Cinsiyet & $\begin{array}{l}\text { Örgüt Geliştirme } \\
\text { Etkililik/Verimlilik }\end{array}$ & Mann-Whitney U & $\begin{array}{l}11179,500 \\
9859,000\end{array}$ & $\begin{array}{l}938 \\
, 066\end{array}$ \\
\hline Medeni Durum & $\begin{array}{l}\text { Örgüt Geliştirme } \\
\text { Etkililik/Verimlilik }\end{array}$ & Mann-Whitney U & $\begin{array}{l}928,500 \\
9665,500\end{array}$ & $\begin{array}{l}, 564 \\
, 981\end{array}$ \\
\hline Yaş & $\begin{array}{l}\text { Örgüt Geliştirme } \\
\text { Etkililik/Verimlilik }\end{array}$ & Kruskal-Wallis & $\begin{array}{l}4,169 \\
2,476\end{array}$ & $\begin{array}{l}\text {,384 } \\
, 649\end{array}$ \\
\hline Ĕ̆itim & $\begin{array}{l}\text { Örgüt Geliştirme } \\
\text { Etkililik/Verimlilik }\end{array}$ & Kruskal-Wallis & $\begin{array}{l}11,023 \\
4,476\end{array}$ & $\begin{array}{l}, 012 \\
, 214\end{array}$ \\
\hline Gelir & $\begin{array}{l}\text { Örgüt Geliştirme } \\
\text { Etkililik/Verimlilik }\end{array}$ & Kruskal-Wallis & $\begin{array}{l}7,944 \\
3,598\end{array}$ & $\begin{array}{l}, 094 \\
, 463\end{array}$ \\
\hline
\end{tabular}

\section{Sonuç ve Tartışma}

Küreselleşmeyle birlikte özellikle iş dünyasında hem değişim hem de rekabet giderek hızlanmaktadır. Bu değişen ve rekabetin kıyasıya yaşandığı çevreye uyum sağlayarak ayakta kalmayı hedefleyen örgütler bu noktada, önceden planlanmış eylemler doğrultusunda hareket etmelidirler.

Stratejik planlama, uzun vadeli amaçlar doğrultusunda hedeflere ulaşmayı öngören bir yapıyı oluşturmaktadır. Stratejik planlanmanın profesyonel bir biçimde yapılıp uygulanmasıyla karmaşıklık ve risk koşulları oldukça azalmaktadır. Stratejik planlama, örgütlere yol gösterici niteliktedir. Neyin nasıl ve niçin olduğunu gösteren yönlendirici olarak da ifade edilebilmektedir.

Bu bağlamda kamu kurum ve kuruluşlarından olan belediyeler, topluma hizmet anlayışını benimsemiş kurumlar olması sebebiyle stratejik planlamaya özel sektör kuruluşlarından daha fazla önem vermek durumundadır. Aksi takdirde topluma sunulan hizmetlerin kalitesi sorgulanır bir vaziyet alır. Buna ek olarak, bu planlamaları kurum çalışanlarının benimsemesi de oldukça büyük önem arz etmektedir. Bağlı bulunduğu kurumun stratejik hedeflerini ve bu hedefler doğrultusunda oluşturduğu stratejik planlarını kendi hedef ve planlaması gibi benimsemeyen çalışanlar süreci aksatabilmekte, bu da topluma sunulacak hizmetleri aksatabilmekte ve de niteliğini düşürebilmektedir.

$\mathrm{Bu}$ çalışmanın amacı, Bursa Yıldırım Belediyesi çalışanlarının stratejik planlama algılarını ölçmektir. Bu amaçla uygulanan anket sonucu elde edilen bulgulara göre, ölçek boyutları olan Etkililik/Verimlilik ve Kurumu geliştirme bağlamında katılımcıların yanıtlarının sosyo-demografik yapılarından cinsiyet, medeni durum, yaş ve gelir karakteristiklerinde istatistiksel olarak anlamlı bir farklılık göstermediği $(p>0,05)$ sonucuna varılmıştır. Bunun sebebinin, stratejik planlamaya ilişkin tutum ve algının henüz belediye çalışanlarında tam olarak oturamamış olması olduğu düşünülmektedir. Buna ek olarak, stratejik planlama özelinde kurum içi verilen eğitimlerin yetersiz olduğu da söylenebilmektedir. Dolayısıyla, sosyo-demografik karakteristikler ne olursa olsun tutum ve algı değişmemektedir şeklinde yorumlanabileceği düşünülmektedir. Bu noktada, çalışmanın literatür bölümlerinde de değinildiği üzere, bilhassa kamu sektöründe stratejik planlamanın ne kadar önem arz ettiği göz önünde bulundurularak, kurum içinde stratejik planlamaya ilişkin bilgilendirmenin ve mümkünse eğitimlerin verilmesinin son derece faydalı olacağı düşünülmektedir. Yine yapılan literatür taramasında daha önce gerçekleştirilen benzer araştırmaların sonuçlarına bakıldığında da bu çalışmanın sonuçlarıyla benzerlik gösterdikleri göze çarpmaktadır. Gelecek çalışmalar için de bu kapsamdaki araştırmaların derinleştirilmesinin hem literatür açısından hem de kamu kurumlarında stratejik planlamaya ilişkin algının sağlıklı bir biçimde yerleştirilerek etkili bir şekilde uygulanması açısından önemli olduğu söylenebilmektedir. 


\section{Kaynakça}

Akgemci, T. (2013). Stratejik Yönetim, 3. Bask1, Ankara, Gazi Kitabevi.

Aşgın, S. ve Yaman, K. (2018). Türkiye'de bakanlıkların stratejik plan uygulamalarında mevcut yapı Ve sürecin değerlendirilmesi, International Journal of Academic Value Studies, 4(19), 449-466.

Aktan, C. C. (2008). Stratejik yönetim ve stratejik planlama, ÇEIS Çimento Endüstrisi İşverenleri Sendikası Yayını, 22(4), 4-21.

Arabacı B. İ. (2007). Stratejik planlamada amaç, misyon, vizyon ve örgütsel slogan gerçekleştirme düzeyini belirlemeye yönelik bir araştırma, A.Ü. Bayburt Ĕ̆itim Fakültesi Dergisi, 2(3), 85-98.

Aydın, M. (2012). Kamu Yönetmeliğinde Stratejik Planlama Ve Stratejik Plan Hazırlama Süreci, Mali Hizmetler Uzmanlığı Araştırma Raporu, Ankara.

Aydın, M. D. ve Aksoy, S. (2007). Kamu kesiminde stratejik planlama ve çalışanlara yansıması: Hacettepe üniversitesi örneği, H.Ü. İktisadi ve İdari Bilimler Fakültesi Dergisi, 25(1), 293-322.

Baloğlu, N.; Karadağ, E. and Karaman, H. (2008). The strategic planning attitude scale: A study of exploratory and confirmatory factor analyses, Educational Sciences: Theory and Practice 8(2), 429-437.

Bayraktar, B. B. ve Yıldız Kakırman, A. (2007). Kurumsal bilginin stratejik planlama sürecinde kullanılması: Bir ilçe belediyesi örneği, Bilgi Dünyası, 8(2), 280-296.

Babbie, E. (2010). The Practice of Social Research, 12th ed. Belmont, CA, Wadsworth Cengage.

Barry, B. (1986). Strategic Planning Workbook for Public and Nonprofit Organizations, St. Paul, Amherst Wilder Foundation.

Bryson, J. (ed.) (1999). Strategic Management in Public and Voluntary Services: A Reader, Oxford, Pergamon.

Dinçer, Ö. (1998). Stratejik Yönetim Ve İşletme Politikası, İstanbul, Timaş Matbaası

Drucker, P. (1999). 21. Yüzyıl İçin Yönetim Tartışmaları, (Çev: İ.Bahçıvangil), İstanbul, Epsilon Yayıncılık.

Durgun, M. (2017). Stratejik yönetim nedir? Neden önemlidir? Yönetim organizasyon alanında güncel yazılar, http://www.yonetselzihin.com/stratejik-yonetim/stratejik-yonetim-nedir-neden-onemlidir/.html (Erişim Tarihi: 09.09.2019).

Genç, N. (2009). Türk kamu yönetiminde stratejik planlama, Dumlupınar Üniversitesi Sosyal Bilimler Dergisi, 23.

Gürer, H. (2006). Stratejik planlamanın temelleri ve Türk kamu yönetiminde uygulanmasına yönelik öneriler, Sayı̧stay Dergisi, sayı 63.

Gürtunca, E. (2010). Kamuda Stratejik Planlama Ve Üç Büyükşehir Belediyesinde Uygulama, Yıldız Teknik Üniversitesi Sosyal Bilimler Enstitüsü, İşletme Anabilim Dalı İşletme Yönetimi Yüksek Lisans Programı Yüksek Lisans Tezi.

Johnson, H. (1994). Strategic planning for modern libraries, Library Management, 15(1), 5-15.

İpekoğlu, H. (2019). Stratejik Planlama Etkililiği Üzerine Bir Araştırma: Ankara Belediyeleri Örneği, Dinçer, E.; Sönmez, S.; Bostancı, M. ve Özçoban, E. (Der.). Sosyal, Beşeri ve İdari Bilimler Alanında Araştırma ve Değerlendirmeler, Ankara, Gece Akademi, 149-178.

Karasu, M. A. (2012). Büyükşehir belediyelerinde stratejik planlama: Karşılaştırmalı bir analiz, Uluslararası Yönetim İktisat ve İşletme Dergisi, 8(16).

Kalkınma Bakanlığ1 (2018). Kamu Daireleri İçin Stratejik Planlama Kılavuzu, 3. Sürüm, http://wwww.sp.gov.tr/upload/xSpKutuphane/files/VrllQ+Kamu_Idareleri_Icin_Stratejik_Planlama_Kilavuzu.p $d f$, (Erişim Tarihi: 21.09.2019).

Küçüksüleymanoğlu, R. (2008). Stratejik planlama süreci, Kastamonu Eğitim Dergisi, 16(2), 403-412.

Orhan, U. ve Er, O. (2018). KOSGEB'de stratejik planlama sürecine ilişkin tutumun değerlendirilmesi: Nicel bir araştırma, Çukurova Üniversitesi İ̈BF Dergisi, 22(2), 409-418. 
Özçam, E. (2007). Büyük İşletmelerde Stratejik Planlama ve Konuya İlişkin Bir Araştırma, Yüksek Lisans Tezi, Dokuz Eylül Üniversitesi Sosyal Bilimler Enstitüsü, İzmir.

Öztop, S. (2007). Stratejik Planlamanın Belediyelere Uygulanması, Yüksek Lisans Tezi, Kocaeli Üniversitesi Sosyal Bilimler Enstitüsü, Kocaeli.

Songür, N. (2008). Belediyelerin stratejik planlama sürecindeki gereklilikleri yerine getirme durumları üzerine bir araştırma, Çağdaş Yerel Yönetimler, 17(4), 63-86.

Strateji ve Bütçe Başkanlığı, (2019). Belediyeler İçin Stratejik Planlama Rehberi, http://wwww.sp.gov.tr/upload/xSpKutuphane/files/2nABM+Belediyeler_Icin_Stratejik_Planlama_Rehberi.pdf

(Erişim Tarihi: 15.09.2019).

Tapinos, E.; Dyson, R. and Meadows, M. (2005). The Impact of Performance measurement in strategic planning, International Journal of Productivity and Performance Management, 54, 5(6). 365-374.

Thompson, J. (2001). Understanding Corporate Strategy, London, Thomson Learning.

Ülgen, H. ve Mirze, S.K. (2010). İsletmelerde Stratejik Yönetim, İstanbul, Beta Yayınları.

Ünaldı, H. (2002). Stratejik yönetim nedir, ne değildir? KOBİ Efor Dergisi, Aralık Sayısı.

Yılmaz, K. (2003). Kamu kuruluşları için stratejik planlama uygulaması, Sayıştay Dergisi, 50-51, 67-86.

Yörük, D. ve Bozok, Y. (2014). Kamu kurumlarında stratejik planlama süreci ve yöneticilerin algisı: Afyon Kocatepe Üniversitesi örneği, Atatürk Üniversitesi İktisadi ve İdari Bilimler Dergisi, 29(1). 